GT2006-90833

\title{
CERAMIC MATRIX COMPOSITE VANE SUBELEMENT BURST TESTING
}

\author{
David N. Brewer \\ Army Research Laboratory, Cleveland, Ohio, USA \\ Michael Verrilli \\ General Electric Aircraft Engines, Cincinnati, Ohio, USA \\ Anthony Calomino \\ NASA Glenn Research Center, Cleveland, Ohio, USA
}

\begin{abstract}
Burst tests were performed on Ceramic Matrix Composite (CMC) vane specimens, manufactured by two vendors, under the Ultra Efficient Engine Technology (UEET) project. Burst specimens were machined from the ends of $76 \mathrm{~mm}$ long vane sub-elements blanks and from High Pressure Burner Rig (HPBR) tested specimens. The results of burst tests will be used to compare virgin specimens with specimens that have had an Environmental Barrier Coating (EBC) applied, both HPBR tested and untested, as well as a comparison between vendors.
\end{abstract}

\section{INTRODUCTION}

The use of ceramics in gas turbine hot sections has been pursued as a solution to the need for increased engine performance[ 1 ]. Increased pressure for higher efficiencies, and lower emissions, has pushed gas path temperatures higher and increased the penalties for cooling allowances and weight. Ceramics, and CMCs, offer the promise of higher temperature operation, lower cooling requirements, lighter weight and increased durability.

Ceramic matrix composites offer increased damage tolerance over conventional monolithic ceramics. CMCs also offer the promise of more reliable performance in larger parts but add increased complexity in part fabrication. CMCs have been demonstrated for use as combustor liners [2-4 ] but the real advantage of CMCs lies in their use in rotating components. The first step on the path to their use as turbine blades begins with successful insertion as turbine vanes or nozzles.

The superalloy parts that CMC applications compete with have a long and successful history to overcome. The damage tolerance of CMCs, over monolithic ceramics, help close the technology gap but material strength, complex part integration and contact stress capability remain problematic. Increased temperature capability and lower density are still the main drivers to insertion of CMC components.

Airfoil shapes with tight tolerances and sharp trailing edges have been more difficult to achieve in CMCs than monolithic materials. Net shape manufacturing has not been developed for CMCs as it has for monolithic ceramics. The successful performance of CMCs in the gas path as aerodynamic parts, such as vanes or blades, requires designs, design tools and fabrication methods to be developed.

The objective of this research was to demonstrate design and fabrication techniques, developed under UEET, have made significant progress toward the application of CMC in cooled aerodynamic parts. Previous analysis of CMC vane shapes subjected to the turbine environment [ 5 ] indicated that maximum stresses occurred in the trailing edge, in the form of interlaminar tensile (ILT) stresses, Figure 1. The stresses resulted from the interaction of mechanical and thermal loading during operation. Burst tests were chosen to best assess the capability of the CMC vane in this critical mode of failure.

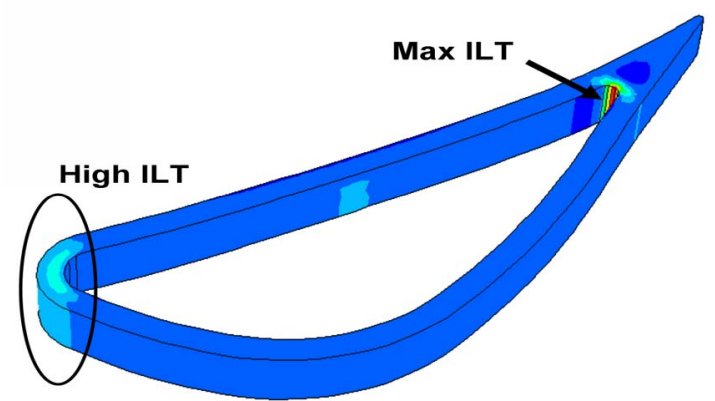

Figure 1- Predicted High ILT Regions

Burst tests were conducted on 12 specimens, from as manufactured parts as well as parts coated with an EBC and 
subjected to a high-pressure gas turbine environment have been conducted. An EBC coated vane, which was not tested in a gas turbine environment, was burst to assess the effect of the coating process on the vane. Two manufactures of CMC vanes, GE Power Systems Composites, LLC and Goodrich, have produced the test articles and the performance of each will be compared.

\section{MATERIAL AND DESIGN SPECIFICATIONS}

The material used to fabricate the vane specimens was developed under the UEET program. The material has been well documented [ 6-8 ] and consists of Sylramic ${ }^{\circledR} \mathrm{SiC}$ fibers with In-Situ BN interface[ 8 ] and a Chemical Vapor Infiltration (CVI), slurry cast and Melt Infiltrated matrix. Because analyses predicted the occurrence of significant interlaminar stresses at the trailing edge, a fabric was developed to provide reinforcement in the high stress region. The Sylramic $\AA$ fibers were woven at Albany Techni-Weave in a unique Y-Cloth [ 9 ] geometry, Figure 2. This fabrication technique makes the sharp trailing edge, required for vane applications, possible. The vane sub-element consisted of six plies of Sylramic ${ }^{\circledR} \mathrm{SiC}$ fiber cloth.

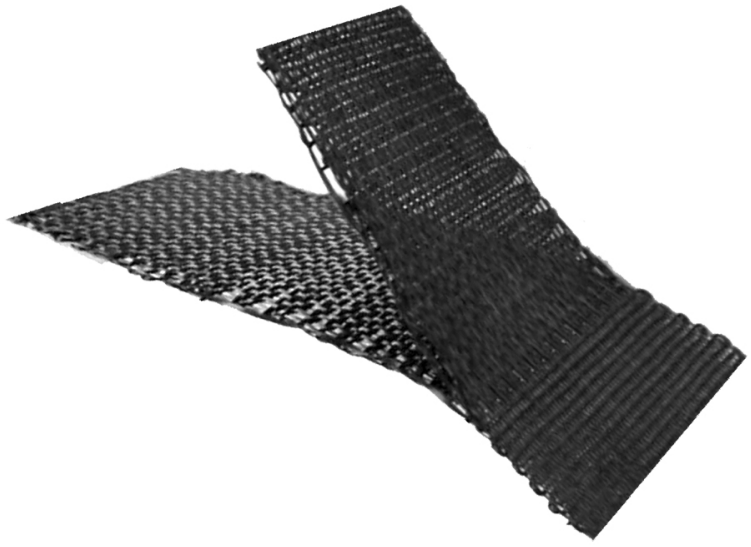

Figure 2 - Sylramic Y-Cloth

The CMC vane geometry was derived from a current super-alloy first stage vane. The length of the vane specimen, as manufactured, was approximately $76 \mathrm{~mm}$ with a constant cross section shown in Figure 1. The vane specimens had a trailing edge radius of $0.3 \mathrm{~mm}$, a wall thickness of $1.5 \mathrm{~mm}$, a leading edge radius of $3.1 \mathrm{~mm}$ and a final machined length of $50 \mathrm{~mm}$, in HPBR test geometry, Figure 3. Several of the burst specimens were cut from the excess material of the subelement.

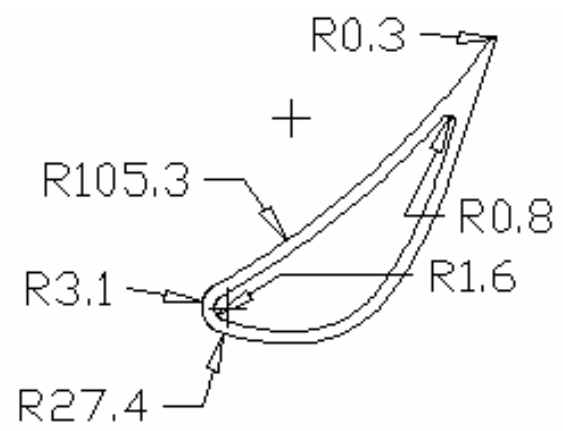

Figure 3 - Geometry of vane sub-element, mm

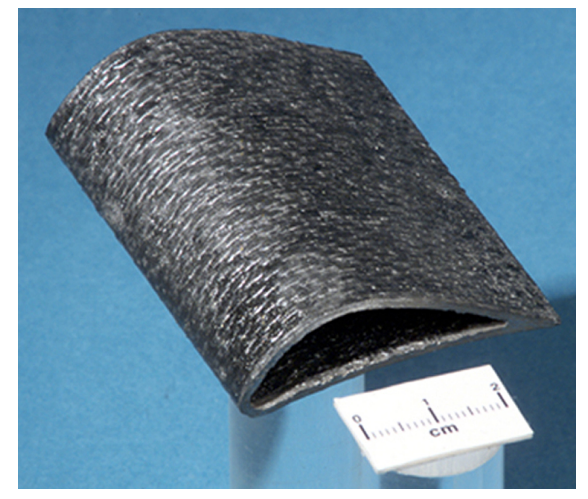

Figure 4 - As Fabricated Vane

\section{TEST SPECIMEN PREPARATION}

Because the primary application of the vane sub-elements was a demonstration in the HPBR [10] at NASA Glenn Research Center, three of the sub-elements were coated with an EBC. The coating system consisted of a silicon bond coat, a mullite intermediate coat, and an experimental rare earth silicate topcoat. A coated $\mathrm{SiC} / \mathrm{SiC}$ vane sub-element is shown in Figure 5.

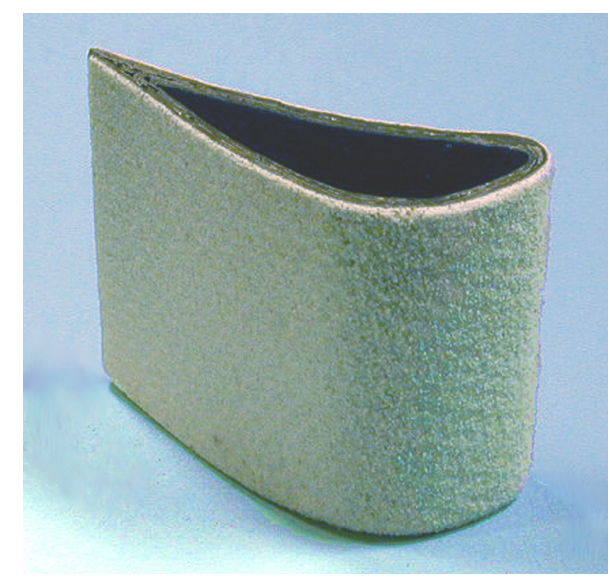

Figure 5 - Vane with EBC

Two test sections were cut from each vane sub-element with a diamond saw, at a thickness of $2.5 \mathrm{~mm}$. A total of 6 vanes were tested resulting in 12 burst specimens. Table 1 identifies the specimen number with the vane, vendor and condition, prior to testing. Strain gages were applied to test specimens. Five gages were applied to the first two specimens that were tested. The number was reduced to two after examination of the results of the first tests results and the need to reduce test complexity. Gages were placed on the pressure and suction sides of the specimens, areas of compressive and tensile strains, respectively. 
Table 1

\begin{tabular}{|l|l|l|l|}
\hline$\#$ & Vane & Vendor & Condition \\
\hline 1 & 904 & GEPSC & Untested w/coating \\
2 & Lot2 Vane 2 & & \\
\hline 3 & 903 & GEPSC & Untested, uncoated \\
4 & Lot1 Vane2 & & \\
\hline 5 & 910 & GEPSC & Untested, uncoated \\
6 & Lot2 Vane1 & & \\
\hline 7 & 910 & GEPSC & $\begin{array}{l}\text { 102 cycles HPBR, } \\
\text { w/coating }\end{array}$ \\
\hline 8 & & GEPSC & $\mathbf{5 0}$ Hr HPBR w/coating \\
\hline 10 & & & \\
\hline 11 & & Goodrich & Untested, uncoated \\
12 & Lot1 Vane2 & & \\
\hline
\end{tabular}

Specimens were cut from HPBR tested vanes 910 and 909. Pre-test conditions for these vanes were conducted as part of a rig test conducted in September of 2003[ 5 ], also under UEET funding. The HPBR was run at a rig pressure of $6 \mathrm{~atm}$ and combustion flow of $0.5 \mathrm{~kg} / \mathrm{sec}$. An air flow of $0.15 \mathrm{~kg} / \mathrm{sec}$ was used to cool the internal cavities of all vanes in the test section.

The test program consisted of 50 hours of steady state operation on specimen 909 . Varying the fuel/air ratio of the rig during operation controlled temperatures. Gas temperatures of 1150 to $1200{ }^{\circ} \mathrm{C}$ were measured downstream of the vane. The peak surface (EBC) temperature of the $\mathrm{SiC} / \mathrm{SiC}$ vane subelement was measured using optical pyrometry at $1170{ }^{\circ} \mathrm{C}$. Testing was performed over the course of 9 days. Cyclic testing was conducted in a single day using a 2-minute cycle on specimen 910. During the 2-minute cycle, the gas temperature was held at a constant minimum value for 45 seconds, then heated to a maximum over 15 seconds, held for 45 seconds, and finally cooled back to the minimum temperature in 15 seconds. The minimum gas temperatures ranged from 900 to $1050{ }^{\circ} \mathrm{C}$ and maximum temperature ranged from 940 to $1440{ }^{\circ} \mathrm{C}$.

The vanes were inadvertently subjected to extremely severe test conditions. Vane 909 was exposed to standing water prior to combustion exposure, because of a undetected cooling leak. Vane 910 was subjected to the deposition of molten superalloy, on the EBC, because of metallic part meltdown. Both conditions lead to damage in the vanes. NDE and microstructural examinations revealed the extent of spallation due to the vaporization of absorbed water, and deposition of molten metal on both the pressure and suction sides of the second vane.[11]

\section{BURST TEST - EXPERIMENTAL SETUP}

Burst tests were performed at Southern Research Institute, Birmingham, AL. A test fixture was fabricated to perform pressurized internal cavity loading. The fixture, Figures 6 and 7 , consisted of two split cylinders, with internal pressurization passages, separated by alignment pins. The cylinders were split lengthwise to facilitate insertion of the specimen and inner tube. The two cylinder assembly was clamped in the axial direction, to keep the cylinders from separating. A flexible bladder or inner tube, formed to the shape of the specimen cavity, was pressurized with silicon oil. The cylinders constrained the flexible bladder, except in separated region where the specimen was located. All testing was conducted at room temperature. Strain gage measurements were recorded along with oil pressure. Loading was conducted slowly over several minutes. Because of difficulties maintaining pressure in the bladder, a consistent loading rate, from specimen to specimen, was not achieved. Loading continued until specimen failure.

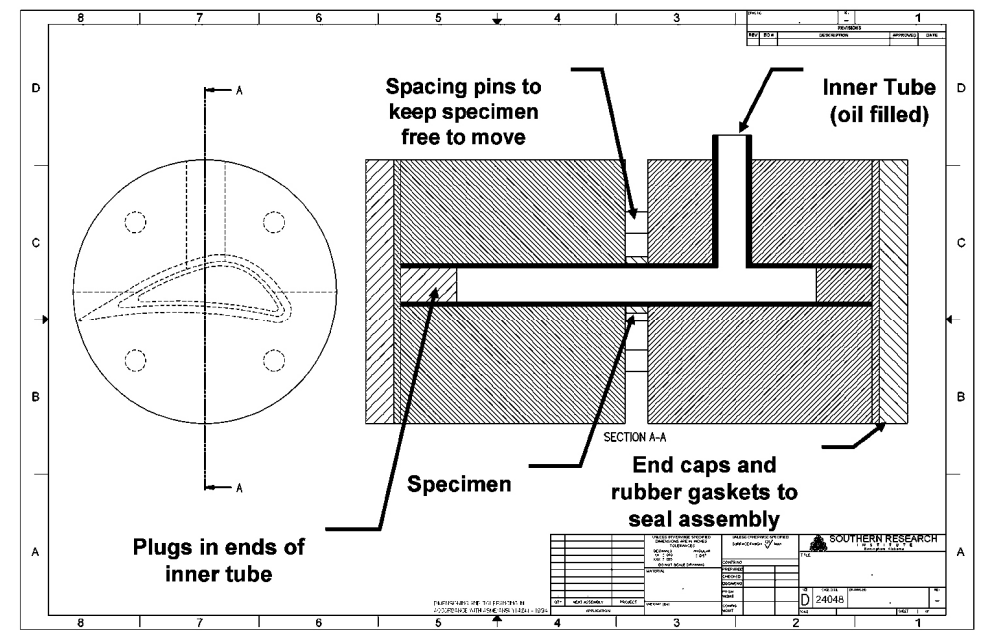

Figure 6 - Burst Fixture Cross-Section

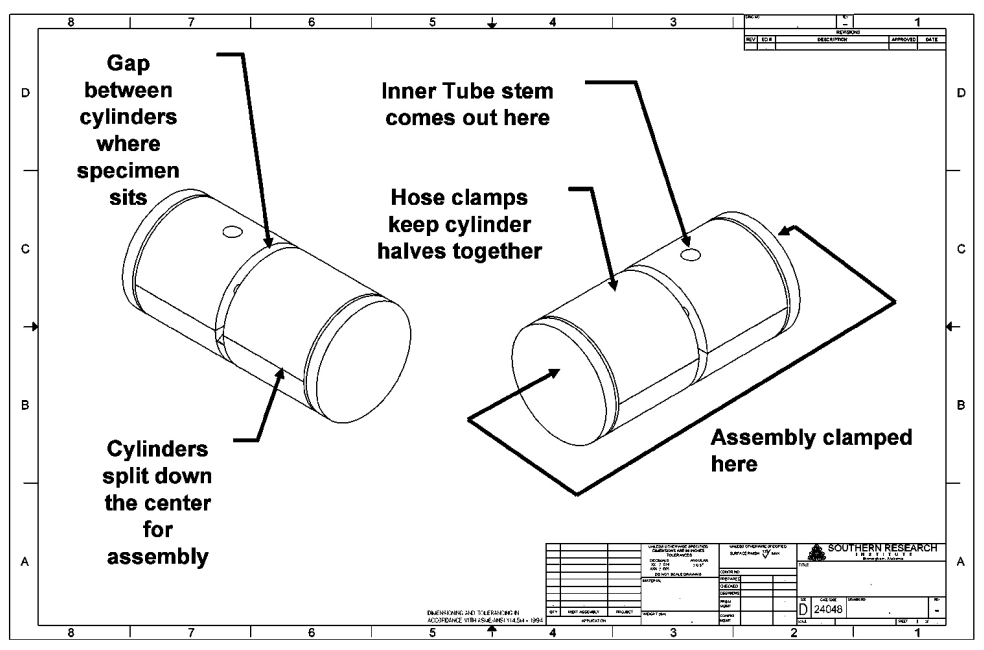

Figure 7 - Burst Fixture Assembly Drawing

\section{RESULTS}

All 12 specimens were tested to failure. Because of problems with bladder leakage, some specimens were reloaded to achieve burst. Figure 8 documents the final condition of the specimens after testing. Clipped wiring shows the approximate location of the strain gages. It is obvious from the figure that residual trailing edge opening is the dominant characteristic.

Typical pressure versus strain plots appear in Figure 9, for five strain gage specimens, and Figure 10, for two strain gage specimens. All specimens exhibited linear or near linear behavior during initial loading. Generally, deviation from 
linear response occurred either as a softening of stiffness or in the form of a jump with decreased stiffness between strains of 0.0004 and 0.001 . Non- linear behavior continued, as a combination of these two mechanisms, until failure.

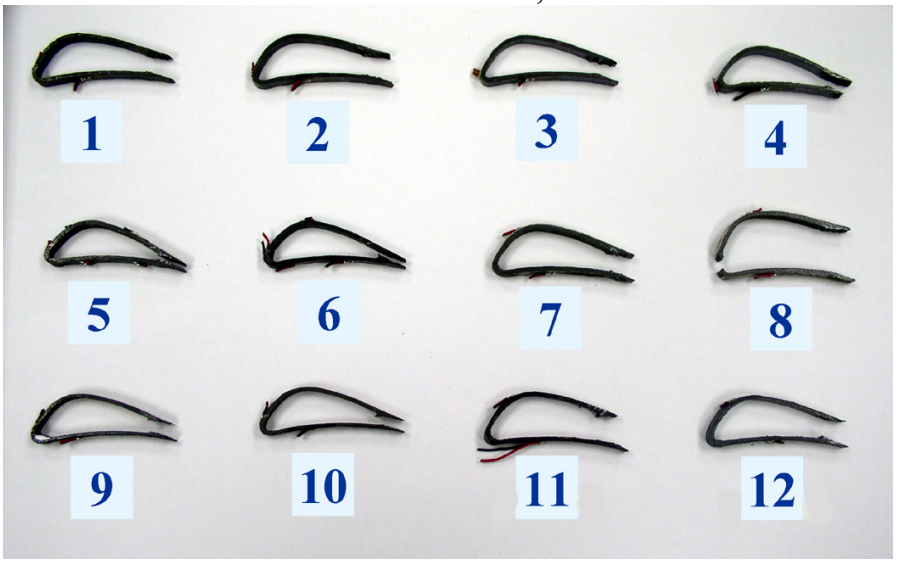

Figure 8 - Specimen Identification

\section{Vane \#5B}

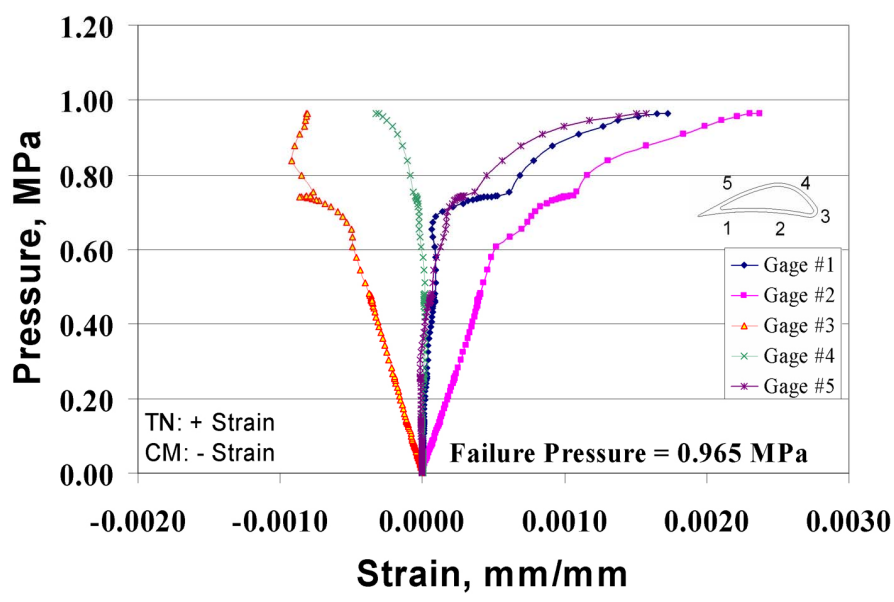

Figure 9 - Typical Pressure vs Strain, 5Gage Specimen

\section{Vane 12}

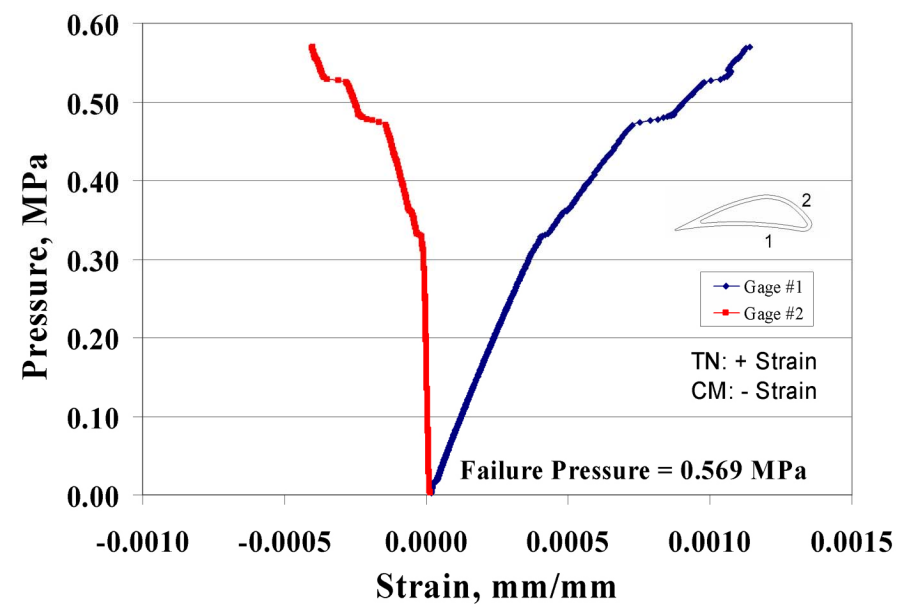

Figure 10 - Typical Pressure vs Strain, 2 Gage Specimen
All vanes specimens failed in interlaminar tension, at the trailing edge, Figure 11. With the exception of one specimen, specimens remained in one piece. Specimen 8 was the only specimen to fail, in secondary mode, at the leading edge as well as the trailing edge. The leading edge failure was a result of failure to control the fixture bladder, at burst.

The failures ran, approximately, through center of the trailing edge, symmetrically. All specimens displayed maximum measured strain in excess of $0.001 \mathrm{~mm} / \mathrm{mm}$. All specimens retained residual crack opening, some to greater degree than others. Specimen did not display out-of-plane distortion. Cracking was observed in the leading edge plies, as predicted by analyses. A summary of the maximum pressures, residual openings and maximum strains appear in Table 2.

Table 2 - Summary of Vane Burst Tests

\begin{tabular}{|c|l|c|c|c|}
\hline $\begin{array}{c}\text { Specimen } \\
\#\end{array}$ & Vane ID & $\begin{array}{c}\text { Max } \\
\text { Pressure } \\
(\mathrm{MPa})\end{array}$ & $\begin{array}{c}\text { Residual } \\
\text { Crack } \\
\text { Opening } \\
(\mathrm{mm})\end{array}$ & $\begin{array}{c}\text { Max } \\
\text { Tensile } \\
\text { Strain } \\
(\mathrm{mm} / \mathrm{mm})\end{array}$ \\
\hline 1 & $\begin{array}{l}904 \\
\text { coated }\end{array}$ & 0.809 & 7.51 & 0.0018 \\
\hline 2 & $\begin{array}{l}904 \\
\text { coated }\end{array}$ & 0.972 & 8.09 & 0.0018 \\
\hline 3 & 903 & 1.06 & 6.85 & 0.0029 \\
\hline 4 & 903 & 0.941 & 4.58 & 0.0018 \\
\hline 5 & 910 & 0.965 & 1.87 & 0.0023 \\
\hline 6 & 910 & 0.989 & 2.06 & 0.0012 \\
\hline 7 & $\begin{array}{l}910 \\
\text { tested }\end{array}$ & 0.666 & 6.94 & 0.0012 \\
\hline 8 & $\begin{array}{l}910 \\
\text { tested }\end{array}$ & 0.633 & Broken & 0.0011 \\
\hline 9 & $\begin{array}{l}909 \\
\text { tested }\end{array}$ & 0.477 & 3.61 & 0.0014 \\
\hline 10 & $\begin{array}{l}909 \\
\text { tested }\end{array}$ & 0.728 & 3.23 & 0.0026 \\
\hline 11 & L1 V2 & 0.963 & 7.27 & 0.0028 \\
\hline 12 & L1V2 & 0.569 & 8.01 & 0.0011 \\
\hline & \multicolumn{1}{|l}{} & &
\end{tabular}

\section{DISCUSSION OF RESULTS}

In a general, most specimens resisted at least $0.650 \mathrm{MPa}$ internal pressure. The failure surface ran symmetrically through the trailing edge and exhibited a tortuous failure path with many broken fiber tows, Figure 11. Clearly, the failure surface was driven through the out-of-plane fibers in the Ycloth, rather than along one single ply. The nonlinear strain records indicate that load was carried as damage proceeded through the trailing edge. This is strong evidence that the Ycloth did the job of resisting interlaminar failure.

Strain data will require additional analyses to interpret results. The magnitude of the strain is very dependent on the placement location on the airfoil. Because of the gage size and the material feature size, location on weave features may cause irregularities. Thus, properties like "stiffness", the slope of strain versus pressure resisted, are not current quantitatively comparable from specimen to specimen. Strain data has been reduced to data of a qualitative nature. 


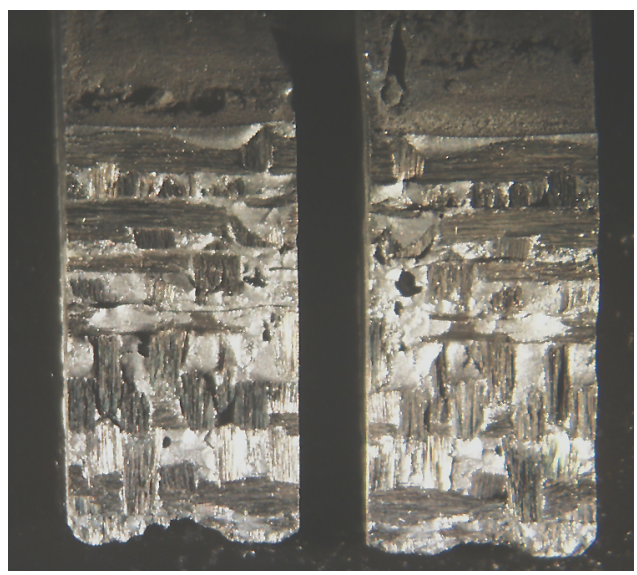

Figure 11 - Specimen 8, Trailing Edge

Examination of leading edge damage supports the analytical conclusion that high interlaminar stresses were present. The qualitative amount of interlaminar ply separation at the leading edge appears commensurate with the residual crack opening at the trailing edge. Specimens 2, Figures 12 and 13, and 5, Figures 14 and 15, were chosen for comparison because they display the greatest and least residual openings, respectively. Figure 13 shows extensive inter-ply cracking at the leading edge of specimen 2. There is very little obvious damage in Figure 15, specimen 5. This result is consistent with the other specimens.

The correlation between residual opening displacement and leading edge damage, coupled with the lack of correlation between residual crack opening and maximum pressure resisted and the lack of out-of-plane distortion indicates that residual stresses from processing are not the cause of the residual opening. The most likely explanation for the residual opening is a wedging of material in the interlaminar ply cracks at the leading edge. This conclusion is supported by the failure of specimen 8 , the only specimen to separate into two pieces. Specimen 8 failed as a result of the inability to control bladder deflections at the end of the test. This damage from over deflection suggests that the residual crack opening is likely an artifact of the test procedure..

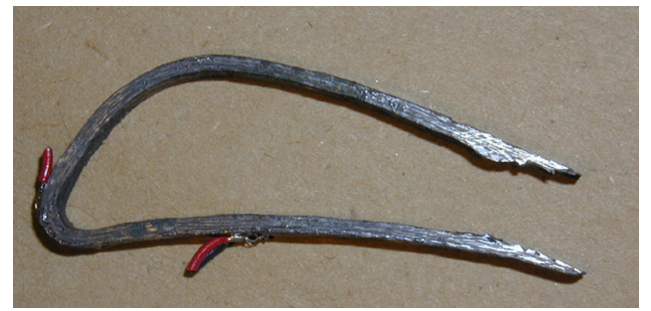

Figure 12 - Specimen 2 Post Test

The consistency of results was very good for within same vane, either in the as fabricated state or after rig testing. Although the sample size is small, the repeatability of the results is reassuring. There was sufficient variation between different vane, different condition samples to make several supportable observations.

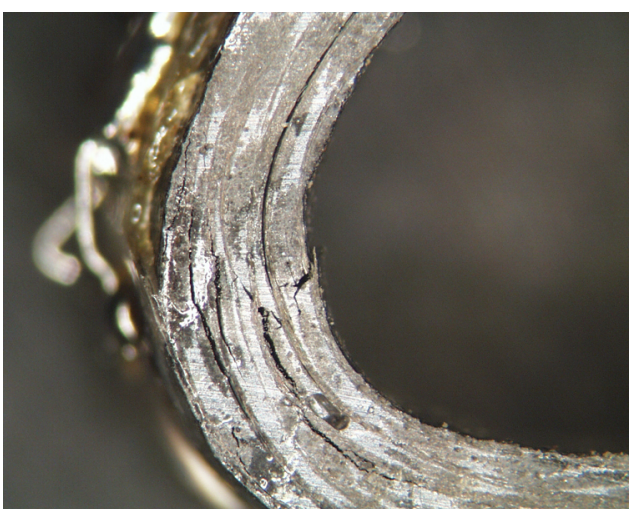

Figure 13 - Specimen 2, Leading edge damage

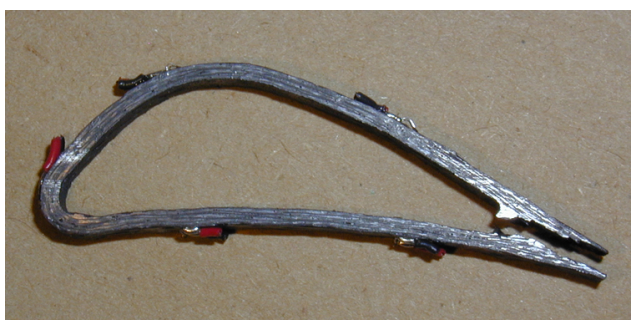

Figure 14 - Specimen 5 Post Test

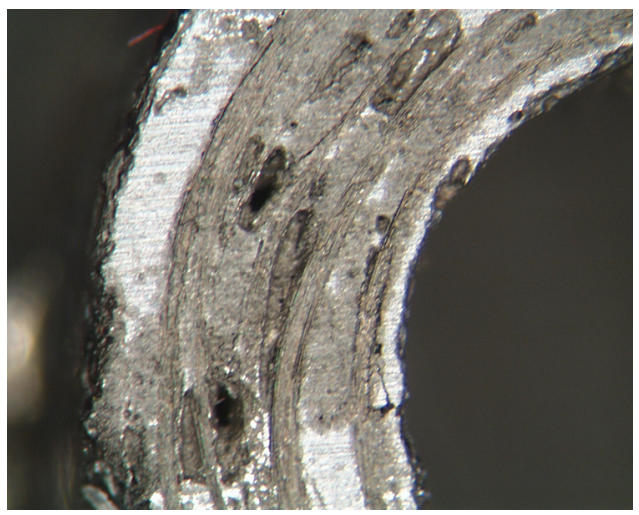

Figure 15 - Specimen 5, Leading edge damage

The consistency of results was very good for within same vane, either in the as fabricated state or after rig testing. Although the sample size is small, the repeatability of the results is reassuring. There was sufficient variation between different vane, different condition samples to make several supportable observations.

The coating process does not appear to significantly degrade the vane performance. Specimens 1 and 2 have been plasma sprayed, at high processing temperature, several times. When compared to specimens 3 and 4, unsprayed specimens of the same manufacturer, the difference in resisted pressure differs by about $10 \%$. Given the sample size, and the expected scatter, this difference would not be enough to raise suspicions of degradation, without additional evidence.

Similarly, there does not appear to be significant difference in damage between $50 \mathrm{hrs}$ steady state exposure and 102 thermal cycles. Specimens 7 and 8, the steady state specimens, showed an average resisted pressure of $0.648 \mathrm{MPa}$ while specimens 9 and 10, the cyclic specimens, demonstrated 0.603 MPa. 
Evidence of possible degradation during HPBR testing can be seen in the maximum pressures sustained. Specimens 1-6 do not have HPBR testing and generally show higher strengths than their tested counterparts, specimens 7-10. Specimens 11 and 12 are excluded from the comparison because they were fabricated by a different vendor. Specimens 5 and 6 were cut from the same vane as specimens 7 and 8 and show higher resisted pressures. The average pressure resisted for the rig exposure specimens is $0.646 \mathrm{MPa}$ compared to $0.975 \mathrm{MPa}$ without rig testing.

Evidence is less suggestive of a difference in performance between vendors. The comparable specimens to study are specimens 3 and 4, GEPSC uncoated - no rig exposure, and specimens 11 and 12, Goodrich uncoated - no rig exposure. The variation of the Goodrich burst pressures makes an averaged comparison suspect. The maximum pressure resisted by a Goodrich specimen is within the scatter of the GE PSC data. The only conclusion to be drawn from observation is that the Goodrich specimens exhibited greater variation than any other specimen group.

Further analysis of the strain data will be conducted. Strains will be compared to FEA predictions to validate the analysis techniques and estimate local stresses in the vane and failure stresses in the trailing edge. The magnitude of nonlinear strains, prior to failure, will be compared to uni-axial characterization tests to estimate the potential strength debit from complex shape fabrication .

\section{SUMMARY AND CONCLUSIONS}

CMC components must demonstrate acceptable designs, consistency in fabrication and adequate durability before they will be inserted into gas turbine engines. Burst tests, by internal cavity loading, were chosen to demonstrate CMC design and fabrication maturity. Vane specimens were machined from $\mathrm{SiC} / \mathrm{SiC}$ composite vane sub-elements that had different histories, from virgin material to those tested in a turbine environment. Test results demonstrated that fabrication consistency is good and that fabrication techniques address a critical failure mode. The results also show that strength, by burst pressure, and damage tolerance, by strain measurement, are acceptable for component performance. These positive results continue to show the potential of CMC composites for turbine airfoil applications.

\section{ACKNOWLEDGEMENT}

The authors like to thank NASA's Ultra Efficient Engine Technology (UEET) program for sponsoring this research and Terry Barnett and Michael Moser of Southern Research Institute for performing the burst testing and documenting the results.

\section{REFERENCES}

[1] Kimmel,J., Price, J., More, K. Torterelli, P., Sun, E., and Linsey, G.,"The Evaluation of CFCC Liners After Field Testing in a Gas Turbine- IV" Proceedings of ASME Turbo Expo 2003, Atlanta, GA, ASME paper GT-2003-38920
[2] Brewer, D., "HSR/EPM Combustion Materials Development Program", Materials Science and Engineering, A261, pp. 284-291, 1999

[3] Corman, G., Dean, A. Brabetz, S. et al,'Rig and Gas Tubine Engine Testing of MI CMC Combustor and Shroud Components" Proceedins of Turbo Expo 2001, June, 2001, New Orleans, ASME paper 2001-GT-0593

[4] Brewer, D., Ojard, G., and Gibler, M., "Ceramic Matrix Composite Combustor Liner Rig Test", Proceedings of Turbo Expo 2000: ASME Turbo Expo, Land, Sea \& Air, May 8-11, 2000, Munich, Germany, paper TE00CER03-03, May, 2000.

[5] Verrilli, M. J., Calomino, A., Robinson, R., Thomas, D., "Ceramic Matrix Composite Vane Subelement Testing in a Gas Turbine Environmental", Proceedings of Turbo Expo 2004: ASME Turbo Expo, Land, Sea \& Air, June 14-17, 2004, Vienna, Austria, ASME paper GT2004-53970.

[6] DiCarlo, J., Yun, H., Morscher, G., Bhatt, R.,"SiC/SiC Composite for $1200 \mathrm{C}$ and Above" NASA TM-2004-213048, November 2004.

[7] Bhatt, R. T., McCue, T. R., and DiCarlo, J. A., "Thermal Stability of Melt Infiltrated SiC/SiC Composites", Ceramic Engineering and Science Proceedings, Vol. 24, Issue 4, 2003, pp. $295-300$

[8] Yun, H. M, DiCarlo, J. A., Bhatt, R. T., and Hurst, J. B., "Processing and Structural Advantages of the Sylramic-iBN Fiber for $\mathrm{SiC} / \mathrm{SiC}$ Composites", Ceramic Engineering and Science Proceedings, Vol. 24, Issue 4, 2003, pp. 247-254.

[9] Calomino, A., Verrilli, M. J., "Ceramic Matrix Composite Vane Subelement Fabrication", Proceedings of Turbo Expo 2004: ASME Turbo Expo, Land, Sea \& Air, June 14-17, 2004, Vienna, Austria, ASME paper GT2004-53974.

[10] Robinson, R. C., "NASA GRC's High Pressure Burner Rig Facility and Materials Test Capabilities", NASA CR-1999209411, December 1999.

[11] Verrilli,M., Calomino, A., R. Craig Robinson, and David J. Thomas, "Characterization Of Ceramic Matrix Composite Vane Subelements Subjected To Testing In A Gas Turbine Environment", Proceedings of Fifth International Conference on High Temperature Ceramic Matrix Composites (HTCMC5), Sept. 12-16, 2004, Seattle, WA. 